\title{
THE STATE OF INTERNATIONAL COMMERCIAL ARBITRATION IN TANZANIA: A COMPARATIVE CRITIQUE AND CALL FOR THE REFORM
}

\author{
Julius Cosmas*
}

\begin{abstract}
This article explores the state of international commercial arbitration law in Tanzania. The Article analyses whether the current legal regime is up to date and in accordance with UNCITRAL Model law perimeters. It is submitted that, for Tanzania to become a regional commercial hub there is a need to ensure that its dispute settlement system meets international standards. One crucial branch of law which needs benchmarking is the arbitration law regime. The article concludes that only after benchmarking its laws to that level will Tanzania not be able to compete commercially with the neighbouring countries of Kenya, Uganda and other countries of the world which have already updated their laws.
\end{abstract}

INTRODUCTION.

I. HISTORICAL DEVELOPMENT OF INTERNATIONAL COMMERCIAL

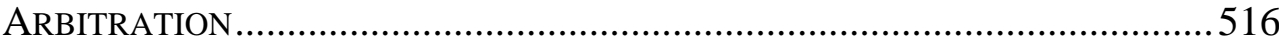

A. The UNCITRAL Model Law as a Benchmark.......................... 517

II. THE LAW GOVERNING ARBITRATION IN TANZANIA ..............................520

III. THE COMPARATIVE ANALYSIS ....................................................... 521

A. Stay of Proceedings .......................................................... 521

B. The Right of Appeal ............................................................. 526

C. Tribunals Powers to Rule on Its Competence ..........................5527

D. Tribunal's Powers to Award Costs and Interest ...................... 528

CONCLUSION..................................................................................529

\section{INTRODUCTION}

Tanzania, as many other developing countries, is actively involved in the scramble for attracting foreign investments and trade. The Country's new phase of embracing foreign investments and trade started in the earliest of the 1990s. ${ }^{1}$ The policy reforms carried out during this period increased the number of approved investments in the country and opened the room for cross border commerce. The United Nations Conference on Trade and Development (UNCTAD) Reports on global FDI inflows indicates that for

\footnotetext{
* Dr. Julius Cosmas (Ph.D), Lecturer in Law, Mzumbe University- Tanzania.

${ }^{1}$ Through National Investment (Promotion and Protection) Act No. 10 of 1990 the second phase government liberalized the economy from the state owned economy to a private oriented economy. The Act was repealed and replaced with the Tanzania Investment Act, Act no. 26 of 1997.
} 
the last two years there has been a significant increase of foreign direct investment (FDI) to Tanzania. ${ }^{2}$ The total FDI in 1992 was 12 million USD only but by the end of 2011 the FDI value has increased to the tune of approximately 1.1 billion USD. ${ }^{3}$ The FDI stock amounted to 388 million USD in 1990 compared to 7.8 billion USD in 2012. ${ }^{4}$

The 2012 record places Tanzania ahead of all East African countries. ${ }^{5}$ The same report has highlighted that between June 2011 and June 2012, Tanzania overtook Kenya-the region's biggest economy. In addition, the report has shown that for the past three years, Tanzania has attracted about 47 percent of all FDI flows in the five East African countries. ${ }^{6}$ This indicates the high confidence among foreign investors in Tanzania. The following table indicates the FDI growth for 2006-2011.

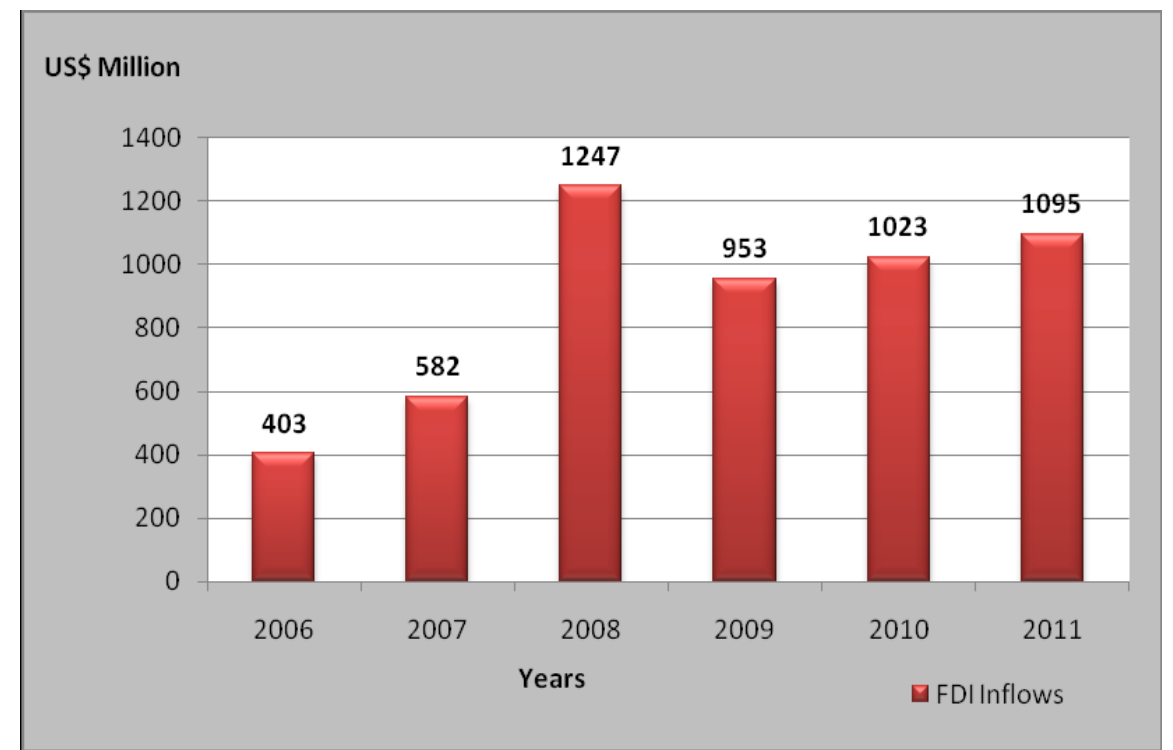

Source: UNCTAD World Investment Report-2012.

Several factors may be responsible for the growth of commerce and investments in the country. The country's geographical positioning, political

\footnotetext{
${ }^{2}$ United Nations Conference on Trade and development (UNCTAD): World Investment Report 2012, http://unctad.org/en/PublicationsLibrary/ldc2012_en.pdf_(last visited Nov. 14, 2013).

${ }^{3}$ United Nations Conference on Trade and development (UNCTAD): World Investment Report 2012, http://unctad.org/en/PublicationsLibrary/ldc2012_en.pdf (last visited Nov. 14, 2013).

${ }^{4}$ Ibid.

${ }^{5}$ United Nations Conference on Trade and development (UNCTAD): World Investment Report 2012, http://unctad.org/en/PublicationsLibrary/ldc2012_en.pdf (last visited Nov. 15, 2013); see also FAO 2012 Report on Trend and Impact of Foreign Investment in Developing Countries Agriculture, http://www.fao.org/fileadmin/user_upload/newsroom/docs/Trends\%20publication\%2012\%20Novem ber\%202012.pdf (last visited Nov. 15, 2013).

${ }^{6}$ UNCTAD (note 3 above) at 5.
} 


\section{THE STATE OF INTERNATIONAL COMMERCIAL 515}

stability, gold productions have played a significant role in this rapid development. ${ }^{7}$ Apart from gold, other precious stones are also found in plenty. Other minerals found in Tanzania include metallic minerals such as gold, iron, silver, copper, platinum, nickel and tin; gemstones such as diamonds, tanzanite, ruby, garnet, emerald, alexandrite and sapphire. ${ }^{8}$ The recent discovery of billions of tones of natural gas with the possibility of crude oil alongside the Indian Ocean makes the country even more attractive to international trade and investments.

All these new developments require a country to put in place a dispute settlement system which can accommodate international commercial disputes. International commercial disputes are normally settled through arbitration mechanism. Therefore, in order for Tanzania to go with the pace and this common practice, it needs to ensure that its arbitration laws are comprehensive enough and capable of resolving international commercial disputes. In addition, there is a need to ensure that strong arbitration institutions are established and manned with people with skills to handle international commercial arbitration disputes.

At international level, the UNCITRAL Model Law is considered as a gauging instrument to determine whether a particular country arbitration laws is up to international standards. ${ }^{9}$ A number of factors are taken into consideration.

This article, therefore, looks at Tanzania Arbitration laws vis a vis the UNCITRAL Model Law on selected aspects. The aspects under consideration are: powers to order stay of proceedings, the parties' right of appeal, tribunal's power to rule on its competence and lastly, tribunal's power to award costs and interests. In addition, the article compares the Tanzanian law vis a vis the Kenya, Uganda and United Kingdom arbitration laws on the same selected aspects.

The article is divided into four Parts. The first part discusses in brief

\footnotetext{
${ }^{7}$ Tanzania is ranked third after South Africa and Ghana, See Gajigo O et al, Gold Mining in Africa: Maximizing Economic Return for Countries, Africa Development Bank Paper Series, Number 147, (Mar. 2012). Available at http://www.afdb.org/fileadmin/uploads/afdb/Documents/Publications/WPS\%20No\%20147\%20Gold \%20Mining\%20in\%20Africa\%20Maximizing\%20Economic\%20Returns\%20for\%20Countries\%2012 0329.pdf (last visited Nov. 20, 2013).

${ }^{8}$ For more information visit the Ministry of Energy and Minerals, http://www.mem.go.tz/AboutUs/MEMOverview/TheMineralSector/tabid/120/language/enUS/Default.aspx (last visited Nov. 15, 2013).

${ }^{9}$ UNCITRAL Model Law on International Commercial Arbitration, adopted by the UN Commission on International Trade Law as amended in 2006. Hereinafter referred as "the Model Law", http://www.uncitral.org/pdf/english/texts/arbitration/ml-arb/07-86998_Ebook.pdf (last visited Jul. 23, 2014).

${ }^{9}$ General Assembly Resolution 40/72 (Dec. 11, 1985).
} 
the historical development of international commercial arbitration. The international community's efforts to harmonise international commercial arbitration laws are clearly discussed in this part. The second part discusses the UNCITRAL Model Law as the gauging instrument. The salient features of the Model Law are discussed. The third part discusses the Tanzania position vis a vis Kenya, Uganda and United Kingdom laws on the selected aspects. While acknowledging the efforts by the High Court and the Court of Appeal of Tanzania, the part submits that there is a need to make a clear legislative effort to define the powers of the Tribunals vis a vis that of the Courts. The fourth and last part is a conclusion. It is concluded that there is a need to reform the Tanzania international commercial arbitration law regime so as to be at per with the Model Law.

The article concludes that the law is outdated and there is a need to reform the same in order to make Tanzania arbitration mechanism as important as its counterpart East African countries of Kenya and Uganda.

\section{HISTORICAL DEVELOPMENT OF INTERNATIONAL COMMERCIAL ARBITRATION}

The modern age saw the development of commercial arbitration during the eighteenth and nineteenth centuries through trade associations, shipping and stock exchanges, and chambers of commerce. ${ }^{10}$ In 1923, the world community made the first effort to harmonise commercial Laws. The efforts started with the Geneva Protocol on Arbitration Clause, $1923 .{ }^{11}$ Later on in 1927, the International Convention on the Execution of Foreign Awards, 1927 (Geneva Convention) was made to supplement the Geneva Protocol. The purpose of the Convention was to enlarge the scope of application of the Geneva Protocol by providing recognition and enforcement of Protocol within the territory of contracting States and not merely the State in which the award is made. ${ }^{12}$ However, in the course of implementation, a number of problems were envisaged. The biggest problem was that the successful party was obliged to seek a declaration in the countries where the arbitration took place of the effect that the award was enforceable in that country before it could go ahead and enforce the award in the courts of the place of

\footnotetext{
${ }^{10}$ Buhring C, Arbitration and MEdiation in InTERnational Business 32 (2 ed. 2006).

${ }^{11}$ The Protocol on Arbitration Clause, 1923 (Geneva Protocol), https://treaties.un.org/doc/Publication/MTDSG/Volume\%20II/LON/PARTII-6.en.pdf (last visited Jun. 23, 2014).

${ }^{12}$ International Convention on the Execution of foreign Awards, 1927 (Geneva Convention).
} 


\section{THE STATE OF INTERNATIONAL COMMERCIAL 517}

enforcement. ${ }^{13}$ That requirement rendered the award ineffective, hence many parties/countries decided not to utilize the Convention.

Due to the inefficiency of the Geneva Convention, the world community sought the need to develop another convention which would address these concerns. The New York Convention on Recognition and Enforcement of Foreign Arbitral Awards of 1958 (hereinafter referred "the Convention") was developed to ensure that once rendered, the award would receive recognition and be easily enforced in all member states. ${ }^{14}$ As of January 2013 the New York Convention has been ratified by 148 member states. ${ }^{15}$ Tanzania ratified the Convention on January $12^{\text {th }}, 1965 .{ }^{16}$

Despite the existence of the New York Convention, it was later discovered that the laws governing Arbitration among member states differs a lot, hence hindering the effectiveness of the New York Convention. As a result, in 1985 the world community through the United Nations Commission on Trade Law (UNCITRAL) developed the UNCITRAL Model Law on Commercial Arbitration Law, 1985. ${ }^{17}$

\section{A. The UNCITRAL Model Law as a Benchmark}

The Model Law was recommended by the United Nations in the General Assembly resolution of 11th December $1985 .^{18}$ The Model law provisions seek to ensure that member states to the UN adopt and have a uniform legal system governing commercial arbitration. The Model Law is based on the principle of parties' autonomy and requires the courts to honour an arbitration clause by staying any proceedings brought before in favour of arbitration. ${ }^{19}$ It is on the basis of this fact that the Model Law has become the gauging instrument in determining whether a particular country arbitration laws meet the international standards. ${ }^{20}$

\footnotetext{
${ }^{13}$ Redfern A \& Hunter M, The Law and Practice of International. Commercial. Arbitration 62 (2 ed. 1989).

${ }^{14}$ The New York Convention, 1958.

${ }^{15}$ See the List of Contracting States, http://www.newyorkconvention.org/contracting-states/list-ofcontracting-states (last visited Jul. 23, 2013).

${ }^{16}$ Ibid.

${ }^{17}$ UNCITRAL Model Law on International Commercial Arbitration, adopted by the UN Commission on International Trade Law as amended in 2006. Hereinafter referred as "the Model Law", http://www.uncitral.org/pdf/english/texts/arbitration/ml-arb/07-86998_Ebook.pdf (last visited Jul. 23, 2014).

${ }^{18}$ General Assembly Resolution 40/72 (Dec. 11, 1985).

${ }^{19}$ Asouzu A, Arbitration and Judicial Powers in Nigeria, 18(6) Journal Of INTERNATIONAL ARBitration 616, 635-36 (2001).

${ }^{20}$ Ibid.
} 
1. World Trend towards Aligning Commercial Arbitration Laws to the Model Law

Many countries have adopted the Model Law. Hong Kong was the first country to adopt it ${ }^{21}$ followed by Australia, ${ }^{22}$ Canada $^{23}$ and Nigeria. ${ }^{24}$ Currently over sixty-five ${ }^{25}$ countries have Legislations based on the UNCITRAL Model Law, out of which nine are African Countries ${ }^{26}$ including neighbours Kenya ${ }^{27}$ and Uganda. ${ }^{28}$ The Tribunal's powers have been jealously protected by specific provisions in the Arbitration Acts of almost all countries which have adopted the Model Law.

\section{The Salient Features of the Model Law}

The Model law was designed to harmonize the law of arbitration for all UN member states. ${ }^{29}$ The Model Law intended to achieve four policy objectives. ${ }^{30}$ The first objective is to limit the role of national court in commercial arbitration and allowing the parties to be free to choose how their dispute will be determined. ${ }^{31}$ The second policy objective is to establish defined core mandatory provisions to ensure fairness and due process in the arbitration proceeding. ${ }^{32}$ Thirdly is to ensure the provision of a framework for the conduct of commercial arbitration, so that in the event of the parties being unable to agree on procedural matters, the arbitration

\footnotetext{
${ }^{21}$ With effect from 6th April 1990. See Sutton B, Hong Kong enacts the UNCITRAL Model Law, 6 ARBITRATION INTERNATIONAL 72, 75 (1990).

${ }^{22}$ Australia Law Standing Committee adopted the Model Law in 1984. See Finlay A, An Overview of Commercial Arbitration in Australia, 4/4 Journal of INTERNATIONAL ARBITRATION 99, 104 (1987).

${ }^{23}$ See Brierly N, Canadian Acceptance of International Arbitration, 40 Maine Law ReVIEw 288, 291 (1988).

${ }^{24}$ Nigeria adopted the Model Law in 1988, see Ezejiofor, The Nigerian Arbitration and Conciliation Act: A Challenge to the Courts, Journal of BusinEss LAW 81, 82(1993).

${ }^{25}$ Visit http://www.uncitral.org/uncitral/en/uncitral_texts/arbitration/1985Model_arbitration_status.html for status (last visited Feb. 13, 2012).

${ }^{26}$ Egypt (1994), Kenya (1995), Madagascar (1998), Mauritius (2008), Nigeria (1988), Tunisia (1993), Uganda (2000), Zambia (2000) and Zimbabwe (1996).

${ }^{27}$ Act No. 4 of 1995 of Laws of Kenya.

${ }^{28}$ The Arbitration and Conciliation Act, 2000 of the laws of Uganda.

${ }^{29}$ Tanzania joined the United Nations on 14th December 1961, see United Nations Member States, http://www.un.org/en/members/countryinfo.asp?countryname=tanzania (last visited Jun. 23, 2014).

${ }^{30}$ See the Preamble to the UNCITRAL Model Law, http://www.uncitral.org/pdf/english/texts/arbitration/ml-arb/07-86998_Ebook.pdf (last visited Jul. 23, 2014).

${ }^{31}$ Ibid.

${ }^{32}$ Ibid.
} 


\section{THE STATE OF INTERNATIONAL COMMERCIAL 519}

would nevertheless be capable of being completed; ${ }^{33}$ and lastly is to establish provisions which would aid the enforceability of awards and clarify certain controversial practical issues. ${ }^{34}$ The intention of the Model Law is to ensure that arbitral institutions have autonomy and are independent from court interference save for few allowances which are meant for support of the arbitration process. ${ }^{35}$

\section{a. Tribunal's Powers}

Article 5, in particular, clearly provides that no court shall intervene except where so provided in this Law. ${ }^{36}$ As a matter of clarification, the UNCITRAL secretariat official commentary states that court intervention is limited by the Model Law because, by opting in an arbitration clause in their agreement, the parties signify clearly their intention to exclude courts for the sake of expediency and finality against protracted battles in court. ${ }^{37} \mathrm{It}$ further states that court should only be called to support arbitration and not obstruct it. It is evident that the Model law to a large extent has managed to limit court intervention in favour of arbitration. ${ }^{38}$

Under the model law, a tribunals has been vested with a number of powers in as far as arbitration proceeding is concerned. The tribunal has power to rule on its own jurisdiction (Kompetenz-Kompetenz), ${ }^{39}$ power to issue peremptory orders, ${ }^{40}$ power to issue interim measures, ${ }^{41}$ power to determine rules of procedure where the parties have not done so, ${ }^{42}$ power to deal with issue of amendment of pleadings unless parties have otherwise agreed, ${ }^{43}$ power to request assistance from a competent court assistance in taking evidence, ${ }^{44}$ and power to correct an error in an arbitral award. ${ }^{45}$ Different jurisdictions which have adopted the Model Law have similar provisions empowering the arbitral tribunal.

\footnotetext{
${ }^{33}$ Ibid.

${ }^{34}$ See UN Doc. A/CN. 9/207 (May 14, 1981) paragraphs 16-17 cited in A. REDFERN \& M .HunTER, LAW AND PRACTICE OF INTERNATIONAL COMMERCial ARbitration 509 (London: Sweet \& Maxwell 1994).

${ }^{35}$ Lew DMJ, Does National Courts Involvement Undermines the International Arbitration Process? 24 AM.U. INT’L L. J 489, 493 (2009).

${ }^{36}$ Model Law supra note 14 Art. 5.

${ }^{37}$ See Explanatory Note of the UNCITRAL Secretariat on the Model Law on International Commercial Arbitration, accessed from www.uncitral.org/english/texts/arbitration/mb-arb.htm; see also U.N. Doc. A/CN.9/264 (Mar. 25, 1985) [reproduced in 16 UNCITRAL Y.B. (1985)].

${ }^{38}$ Supra note 16 Art. 5.

${ }^{39}$ Ibid, Art. 16.

${ }^{40}$ Ibid, Art. 25.

${ }^{41}$ Ibid, Art. 17.

42 Ibid, Art. 19.

${ }^{43}$ Ibid, Art. 24.

${ }^{44}$ Ibid, Art. 27.

${ }^{45}$ Ibid, Art. 33.
} 


\section{b. National Court's Powers}

To ensure support to the arbitration proceedings, national courts of the seat of arbitration and those of the seat of enforcement have been vested with powers as well. The Model Law provides for ten instances under which court intervention is entertained. The first instance is where an action which is subject to arbitration is brought before the court. ${ }^{46}$ Under such a circumstance and in honour of the principle of party autonomy, the court is required to rule in favour of arbitration and dismiss the application before it. Secondly court can intervene where a party to an arbitration agreement requests an interim measure of protection before the tribunal is formed. ${ }^{47}$ Thirdly, an intervention is allowed where parties have failed to agree on the appointment of an arbitrator. ${ }^{48}$ The fourth instance where the court has power to intervene is where there is an application by party challenging the appointed arbitrator. ${ }^{49}$ The fifth instance where intervention may be allowed is where the court is requested to decide on the termination of the mandate of an arbitrator. ${ }^{50}$ In addition to that, court can be approached to decide on the jurisdiction of the arbitral tribunal. ${ }^{51}$ The seventh scenario is when the tribunal requests assistance from the court in taking evidence of the proceedings. ${ }^{52}$ Another instance which requires court intervention is where a party applies to a court to set aside an arbitral award. ${ }^{53}$ Lastly the court assistance will be required where a party seeks recognition or enforcement of an arbitral award. ${ }^{54}$ Therefore, in summary, there are five crucial instances where the court intervention is inevitable: appointment and challenges of arbitrators, order for interim reliefs, review of fundamental jurisdiction of the tribunal, challenge of award and lastly seeking recognition and enforcement of the award.

\section{THE LAW GOVERNING ARBITRATION IN TANZANIA}

In Tanzania, Arbitration is governed by the Civil Procedure Code, Cap 33 R.E. 2002 (CPC) and the Arbitration Act, Cap 15 R.E. 2002 and rules made there under. The current Tanzania Arbitration Act was enacted on May 22nd, 1931 by the Tanganyika Legislative Council. Hence the

\footnotetext{
${ }^{46}$ See the Model Law Art. 8.

${ }^{47}$ Ibid, Art. 9.

${ }^{48}$ Ibid, Art. 11.

${ }^{49}$ Ibid, Art. 13.

${ }^{50}$ Ibid, Art. 14.

${ }^{51}$ Ibid, Art. 16(3).

${ }^{52}$ Ibid, Art. 27.

${ }^{53}$ Ibid, Art. 34.

${ }^{54}$ Ibid, Art. 35 \& 36.
} 


\section{THE STATE OF INTERNATIONAL COMMERCIAL 521}

arbitration law in force to date survived not only colonialism but it has also enjoyed four decades of a free Tanzania. ${ }^{55}$ Despite its existence for about eight decades, the act has passed through very few amendments. ${ }^{56}$ This should not be taken as a sign that the Act is irrelevant in practice nor that the legislature achieve perfection. The act is obsolete on a number of aspects including the central theme of this article, court's role in arbitration proceedings. One important thing to note is that the Act is highly influenced by the then English Arbitration Act of $1889^{57}$, which was repealed fifty years ago.

\section{THE COMPARATIVE ANALYSIS}

In the light of the tribunal's powers and court's powers identified above, this article intends to analyse the extent to which Tanzanian laws adheres to these division of powers stipulated by the model law. Considering the page limits provided, this article will make a comparative analysis on the selected jurisdictions (Kenya, Uganda, UK and Tanzania) laws on four selected aspects of the model law. The aspects under consideration are: the court power of stay of proceedings, the right to appeal to the court of law, tribunal's power to rule on its jurisdiction and tribunal powers to award cost and interest. It is concluded that Tanzania Arbitration regime is lagging far behind and the review of the same is long overdue.

\section{A. Stay of Proceedings}

The above mentioned legislations from different countries demand the courts to stay any court proceedings in favour of arbitration. The wording used by these legislations and the Model Law is 'shall' but not 'may' which appears in Tanzania Arbitration Act. Following hereunder is a discussion showing Court's role in staying any court proceeding in Kenya, Tanzania, Uganda and UK laws.

\section{Kenya}

In Kenya, the general approach on the role and intervention of the court

\footnotetext{
${ }^{55}$ Tanzania Mainland (Tanganyika by then) was under British Dominion since 1920 and got its independence from Britain on December $9^{\text {th }}, 1961$.

${ }^{56}$ Amended by Act no. 32 of 1932 and Act no 10 of 1971.

${ }^{57}$ The Act was repealed and replaced by the Arbitration Act of 1950 which was replaced later by the English Arbitration Act of 1979. Currently the UK has the new Arbitration Act of 1996 which replaced the 1979 Act.
} 
in arbitration is provided in section 10 of the Arbitration Act 1995. The section provides: ...except as provided in this Act, no court shall intervene in matters governed by this Act.

The section, clearly in mandatory terms, restricts the jurisdiction of the court to only such matters as provided for by the Act. This section epitomizes the recognition of the policy of party's autonomy which underlies the arbitration generally. In Kenya the Arbitration $\mathrm{Act}^{58}$ is also very advanced and cope with the model law as it compels the court to order the stay of a proceeding where the parties had contemplated arbitration as a means of settling their dispute if arises.

\section{Uganda}

The Ugandan Arbitration and Conciliation Act, 2000 provides under section 9 that; ... Except as provided in this Act, no court shall intervene in matters governed by this Act.

In addition, Section 5 of the Arbitration and Conciliation Act, $2000^{59}$ provides that;

(1) A judge or magistrate before whom proceedings are being brought in a matter which is the subject of an arbitration agreement shall, if a party so applies after the filing of a statement of defence and both parties having been given a hearing, refer the matter back to the arbitration unless he or she finds;

(a) that the arbitration agreement is null and void, inoperative or incapable of being performed; or

(b) that there is not in fact any dispute between the parties with regard to the matters agreed to be referred to arbitration.

(2) Notwithstanding that an application has been brought under subsection (1) and the matter is pending before the court, arbitral proceedings may be commenced or continued and an arbitral award may be made.

It should be noted here, however, that the Ugandan Act is somehow eccentric as it requires the defendant to file the written statement of defence before applying for the stay of the proceeding. It also requires the court to hear both parties before it could return the matter to an arbitrator. One may argue that the Ugandan law is somehow clinging backward from letting parties go to arbitration. Such a position is contrary to the fourth modern approach or principle regarding the power of the court to honour the parties'

\footnotetext{
${ }^{58}$ Arbitration Act, Act No. 4 of 1995 of laws of Kenya.

${ }^{59}$ Chapter 4 of the Laws of Uganda.
} 


\section{THE STATE OF INTERNATIONAL COMMERCIAL 523}

intention $^{60}$. The party making the application for stay must not have taken steps in the proceedings to answer the substantive claim. For instance, the party must not have served defence or taken another step in the proceedings to answer the substantive claim. The rationale of this requirement is to ensure that stay of proceedings for reference to arbitration is not used as a delay tactic by the defence. The reasoning is that by taking steps to answer the substantive claim, the party submits or is at least taken to be submitting to the jurisdiction of the court and electing to have court deal with the matter rather than insisting on the right to arbitration ${ }^{61}$.

\section{United Kingdom}

The general key principles of arbitration have received a restatement in section 1 of Arbitration Act, 1996 of United Kingdom as follows:

(a) the object of arbitration is to obtain the fair resolution of disputes by an impartial tribunal without unnecessary delay or expense;

(b) the parties should be free to agree how their disputes are resolved, subject only to such safeguards as are necessary in the public interest. ...

If one affords the above principles a literal interpretation, then, it becomes apparent that court's intervention is to be restricted as far as it may result in unnecessary delay and expense in the arbitration. Further, the object of intervention of the court should be to guarantee fair and impartial resolution of disputes. Even more importantly, it is crucial that parties' autonomy is not to be restricted unnecessarily by courts except in public interest.

\section{The Position under Tanzania Arbitration Act}

Under the Tanzanian Arbitration Act, a party to the arbitration agreement who is unhappy with the arbitration clause has a chance to ignore the arbitration clause and successfully sue in court despite the fact that the arbitration clause is in place. The letters of S. 6 of the Act favours this position as it does not oblige the court to stay any proceeding brought before it which has an arbitration clause; instead the court is left with the discretion to stay. The section reads;

Where a party to a submission to which this Part applies, or a person claiming under him, commences a legal proceedings against any other party to

\footnotetext{
${ }^{60}$ Op cit Russel, at 301.

${ }^{61}$ Ibid, RusSELL ON ARBitRation 301 (23rd Ed., London: Sweet \& Maxwell).
} 
the submission or any person claiming under him in respect of any matter agreed to be referred, a party to the legal proceedings may, at any time after appearance and before filing a written statement or taking any other steps in the proceedings apply to the court to stay the proceedings; and the court, if satisfied that there is no sufficient reason why the matter should not be referred in accordance with the submission and that the applicant was, at the time when the proceedings were commenced, and still remains, ready and willing to do all things necessary for the proper conduct of the arbitration, may make an order staying the proceedings.

It is our submission that this section erodes the parties' autonomy principle and ultimately rendering the arbitration agreement/clause futile. It is further argued that the provision brings uncertainty, and could cause delay and ultimately lead to the shrink of arbitration industry in the country. The true nature and function of an arbitration clause was well-explained by Lord Macmillan way back in 1942 in the case of Heyman v. Darwins Ltd ${ }^{62}$ that;

Arbitration clause embodies the agreement of both parties that if any dispute arises with regard to the obligation which the one party has undertaken to the other, such dispute shall be settled by a tribunal of their own constitution. And there is this very material difference, that whereas in an ordinary contract the obligation of the parties to each other cannot in general be specifically enforced and breach of them results only in damages, the arbitration clause can be specifically enforced by the machinery of the Arbitration Acts. The appropriate remedy for breach of the agreement to arbitrate is not damages, but is enforcement. $^{63}$

It is worth noting here, however, that the discretion given to the court by the Act is exercised with due care by our courts. Kudos to the court of Appeal of Tanzania for its respect and honour of arbitration agreement. In Construction Engineering and Builders vs. Sugar Development Corporation $^{64}$, the Court of Appeal was asked to decide on the role of an arbitration clause in a construction contract. The parties had an arbitration clause enshrined in the contract. At a later stage when the dispute arose, the appellant filled a suit in the High Court. The respondent after being served with a copy of the plaint, immediately appeared before the High Court and applied for a stay of the proceeding pursuant to Section 6 of the Arbitration Ordinance. The application was granted. On appeal against the order of stay, the appellant argued that the learned High Court Judge erred by exercising his discretion to order stay because the differences between the parties were not within the scope of the arbitration clause. On appeal to the Court of Appeal, their Lordship correctly held that;

\footnotetext{
62 (1942) AC 356 at 375.

${ }^{63}$ Emphasis is mine.

${ }^{64}$ (1983) TLR 13.
} 


\section{THE STATE OF INTERNATIONAL COMMERCIAL 525}

(1) N/A

(2) Where it is clear that the parties to a contract have agreed to submit their dispute or differences arising under the contract to an arbitrator, the dispute must go to arbitration unless there is good reason to justify the court to override the agreement of the parties.

In another case, Tanzania Motor Services Ltd \& ors vs. Mehar Singh T/A Thaker Singh ${ }^{65}$, the Court of Appeal cemented the same position. The facts in brief were that the respondent had instituted Civil Case No. 20 of 2002 before the High Court instead of invoking the arbitration clause in the contract. The Trial judge refused to stay the proceeding and entertained the matter before him. The appellant on his part filed the petition in order to enforce and bring into play the arbitration clause stipulated in the contract. The petition was refused hence an appeal to the Court of Appeal of Tanzania. The court (Lubuva, J. A., Mroso, J. A. And Nsekela, J.A) held;

... [T] he decision of the learned judge refusing to stay the proceedings in Civil Case No. 20 of 2002 pending a reference to arbitration finally determined the petition by barring the parties from going to arbitration. The decision closed the door to arbitration thus rendering provisions in contracts for arbitration meaningless. They are meant to serve a purpose. We pointed out before that an arbitration clause in a contract is distinct from the other clauses and that its breach can be specifically enforced by the machinery of the Arbitration Act.

It is our submission that the discretion allowed by section 6 of the Act promulgated the learned trial judge to disregard the arbitration clause as the provision wording is 'may' but not 'shall'. Had it been 'shall', the judge ought to have mandatorily stayed a proceeding before the High Court. In another case Nor Consult A/S vs TanRoads ${ }^{66}$ the Commercial Division of the High Court, ruling in favour of arbitration held;

In its supervisory role, courts may penalize and should endeavour to prevent parties from becoming mischievous, and exercise delaying tactics to stall or make impotent the dispute settlement process, noting that arbitration proceedings must be fast tracked, and that a show of professionalism and good faith is vital in this aspect.

While it is true that Courts in Tanzania has shown positive move of leaving a dispute to arbitration where the parties have chosen, it is submitted here that there is a need for the legislation itself to be amended to reflect this positive court position. Without such amendment, it will be unsurprising to see a notorious judge ruling against stay of court proceedings in a near

\footnotetext{
${ }^{65}$ Civil Appeal No. 115 of 2005.

${ }^{66}$ Misc. Commercial Application No. 10 of 2008 (Unreported).
} 
future. If that undesired confusion happens in the High Court where there is no precedence principle, the uncertainty may take ages to clear. It is because of the danger and likelihood of such uncertainty that we call for the amendment of section 6 so that it becomes harmonised and in consonance with the Model Law and other jurisdictions’ provisions discussed above.

\section{B. The Right of Appeal}

In many common law jurisdictions which have adopted the Model Law, the right to appeal against the award is guaranteed. Under the English Arbitration Act, ${ }^{67}$ where there is a serious irregularity or a question of law involved, a party is entitled to appeal to the High Court against such award. $^{68}$

The same provision is found under the Kenya Arbitration Act as it allows appeal against the award where the parties have clearly indicated so in their agreement. ${ }^{69}$ Under section 39 of the Act, an award may be appealed against on questions of law but only if the parties have so agreed. The appeal must be lodged in the High Court, and a further appeal lies to the Court of Appeal, if the parties have so agreed. On such application or appeal, the High Court has two options available to it. It can either determine the question of law arising or confirm, vary or set aside the arbitral award or remit the matter to the arbitral tribunal for re-consideration. ${ }^{70}$ In addition, the High Court or Court of Appeal must accord the appellant special leave to appeal. These powers under S. 39 are in addition to powers to set aside an award as provided under S. $35 .^{71}$

However, the Tanzania Arbitration Act does not recognise the right of appeal against the award. Section 32 provides for the finality of the award and its meaning. Paragraph 8 of the First Schedule of the Arbitration Act clearly provides that the award shall be final and binding upon the parties and all parties claiming under it. On the other hand, the Civil Procedure Code under Rule 21(2) of the Second Schedule provides clearly that no appeal shall lie from a decree arising from a judgment pronounced from an award. The only remedy available for an aggrieved party is to apply to the court to set aside the award. The court is empowered to set aside the award where the arbitrator or umpire has mis-conducted himself or the award has

\footnotetext{
${ }^{67}$ The Arbitration Act, 1996.

${ }^{68}$ Ibid, see s.67, 68 and 69 respectively.

${ }^{69}$ See Section 17 of the Kenya Arbitration Act.

${ }^{70}$ See Section 39 of the Kenyan Arbitration Act, 1995.

${ }^{71}$ See Section 35 of the Kenya Arbitration Act providing for grounds of setting aside an award to include among others, substantive jurisdiction issues and serious irregularities.
} 


\section{THE STATE OF INTERNATIONAL COMMERCIAL 527}

been procured improperly. ${ }^{72}$ The effect of setting aside is to remove the arbitrator and set up a new tribunal to determine the matter afresh. ${ }^{73}$ In other circumstances, the court may order correction or remit the award to the same arbitrator for reconsideration. ${ }^{74}$

While the author recognizes the importance of limiting court intervention in arbitration proceedings, we find it's important to highlight here that in cases where there is a serious error on a point of law, courts should be called up to rectify the same. Parties when so chose should be at liberty to seek assistance from the highest organ entrusted with the dispensation of justice in Tanzania as per Article 107A of the Constitution. It follows, therefore, that the court is the right organ to give a final interpretation of our laws, including arbitration laws. It also submitted here that the right to appeal is a constitutional right which needs to be jealously safeguarded by our courts. Therefore, as a matter of right, parties should be given the right to appeal to the higher court for any point of law involved in arbitration just like in other legal disputes. Modern legislations from other countries have clear provisions to that effect, Tanzania should follow suit in order to have better commercial environment.

\section{Tribunals Powers to Rule on Its Competence}

As opposed to the arbitration laws of other countries including that of its neighbour Kenya, ${ }^{75}$ the Tanzanian legislation does not specifically empower the arbitral tribunal to determine its own jurisdiction/ competence. ${ }^{76}$ Under the Kenyan law, the arbitral tribunal may rule on its own jurisdiction. Such ruling may encompass matters including existence or validity of the arbitration agreement. The fact that a party has appointed or participated in appointing an arbitrator is not a bar to challenging the jurisdiction of the arbitral tribunal. The Act requires that a plea of Kompetenz-Kompetenz be raised latest at submission of defence. ${ }^{77}$

The same position is maintained under the English Arbitration Act. Section 30 of the English Arbitration Act 1996 provide that, unless parties agree, otherwise, the arbitrator may have jurisdiction to decide on the

\footnotetext{
${ }^{72}$ See Section 16 of the Arbitration Act.

${ }^{73}$ See section 18 of the Arbitration Act.

${ }^{74}$ Ibid.

${ }^{75}$ The Kenya Arbitration Act, 1995 section 17 \& 18 (1) (a)—(c).

${ }^{76}$ See Section 11 of the Act, the Arbitrators power is limited to administer oath to the parties, correct an award, issue an award.

${ }^{77}$ Kompetenz-Kompetenz is the German expression short for an arbitrator has competence to rule on its own competence.
} 
validity of the arbitration agreement, proper constitution of the tribunal and legality of reference to the arbitration. Accordingly, pursuant to Section 31 of the Act, a party who wishes to challenge the jurisdiction of the arbitrator must do so at the outset, before taking any step to answer the case on merit.

It is submitted here that Kompetenz-Kompetenz is an important tool in facilitating speed of an arbitration proceedings. Lack of such powers leaves a room for unscrupulous respondents to approach the court and question the jurisdiction of the arbitral tribunal for the sake of delaying the proceedings.

\section{Tribunal's Powers to Award Costs and Interest}

In Kenya, under section 32B of the Arbitration Act, it is clear that where there is no any agreement to the contrary, an arbitral award may include provision for the payment of simple or compound interest calculated from such date, at such rate and with such costs as may be specified in the award. ${ }^{78}$ The section defines costs as legal and other expenses of the parties, fees and expenses of the arbitration as legal and other expenses of the arbitral tribunal. The arbitral tribunal may also exercise discretion to determine and award other expenses related to the arbitration.

In the same spirit of the Kenyan Law, the English Arbitration Act also provides for the Tribunal Power to make an award on interest. Section 49 empowers the Arbitrator to award interest unless the parties have previously agreed otherwise. Subsection 4 of Section 49 reads:

The tribunal may award simple or compound interest from the date of the award (or any later date) until payment, at such rates and with such rests as it considers meets the justice of the case, on the outstanding amount of any award (including any award of interest under subsection (3) and any award as to costs).

The position is not that clear under Tanzania Arbitration Act. The CPC sheds some light on the matter as it provides that the court may order costs in a reference where the award is silent. ${ }^{79}$ Through the CPC it seems (that) the arbitrator can discretionally award costs if satisfied that the arbitration agreement is silent on cost. ${ }^{80}$ This position was stated in Mvita Construction Company Ltd $v$ Tanzania Habours Authority. ${ }^{81}$ In this case, the arbitrator referred the matter to the High Court pursuant to S. 11 (b) seeking guidance as to whether an Arbitrator has power to award interest in an arbitration proceeding. Msumi JK (as he then was) opined that reliefs such as interest

\footnotetext{
${ }^{78}$ The Kenyan Arbitration Act as amended in 2009.

${ }^{79}$ See Rule 13 of the Second Schedule to the CPC.

${ }^{80}$ See Rule 9 and 13 of the Second Schedule to the CPC.

${ }^{81}$ Miscellaneous Civil Case No. 138 of 1998 (Unreported).
} 


\section{THE STATE OF INTERNATIONAL COMMERCIAL 529}

and costs are usually recoverable in court, hence arbitrator should have the same powers. It can be deduced from the opinion that the Honourable Judge gave the purposive interpretation considering that the Act is silent on the matter. As earlier stated, in Tanzania Arbitration Act, there are no corresponding or similar provisions on interest and cost as found in Kenya and English Arbitration laws.

It is submitted here that lack of clear provisions on whether the arbitral tribunal has power to award costs and renders the ADR mechanism impotent. There is a need to have clear provisions which give enough powers to arbitrators to resolve the disputes without unnecessary knocking on court's door for assistance. Powers to award costs and interest are very crucial to any adjudicative process.

\section{CONCLUSION}

In conclusion, it can be said that while the Court has shown a progressive trend in honour of arbitration, there is still a need to have the law itself amended to reflect such progressive positions. As the 2012 record places Tanzania ahead of all East African countries by hosting $47 \%$ of all Foreign Direct Investment to the region, ${ }^{82}$ it becomes even more important to have a suitable legal regime to deal with commercial disputes. It is further submitted here that arbitration has become an important adjudication process in the modern world hence embracing it is vital to any country involved in the modern liberal economy. It is our call that the government should consider amending the Arbitration Act so as to go hand in hand with the country liberalized economy which requires modern laws to prosper.

\footnotetext{
${ }^{82}$ United Nations Conference on Trade and development (UNCTAD): World Investment Report 2012, http://unctad.org/en/PublicationsLibrary/ldc2012_en.pdf; see also FAO 2012 Report on Trend and Impact of Foreign Investment in Developing Countries agriculture, http://www.fao.org/fileadmin/user_upload/newsroom/docs/Trends\%20publication\%2012\%20Novem ber\%202012.pdf (last visited Jun. 12, 2014).
} 